\title{
THE INTERRELATIONSHIP AMID CHARACTERISTICS OF FLEXIBILITY AND BARGAINING STYLE WITH THE PERCEIVED VALUE GAINED AMONGST NEGOTIATORS IN THE HI-TECH BUSINESS SECTOR
}

\author{
ALON EFRAT $^{*}$
}

\begin{abstract}
In today's business market, a modern negotiator needs to change or persist in behavior according to changing internal and external circumstances. This study explores how flexibility and bargaining style influence the social-psychological outcomes valued subjectively as consequences of negotiations from the high-tech sector. 39 respondents from the High-tech arena who by virtue of their position have access to customers or suppliers took part in this study. Quantitative analysis was used to perform hypothesis testing, by using a four-chapter closed structured questionnaire data collected as an instrument. Fndings show that those with a positive perception of change tend to perceive high subjective value. The collaborative and compromising styles appear to have a strong moderating effect on the connections between Psychological Flexibility and Subjective Value Inventory. Those with a collaborative and compromising approach to negotiation tend to combine elements of flexibility to achieve higher subjective value from the negotiating process and outcome.
\end{abstract}

Keywords: Negotiations, Bargaining, Flexibility, Thomas-Kilmann conflict mode instrument, Subjective value

\section{INTRODUCTION}

Over and above building descriptive models of negotiation strategies and providing an explanation of people's behavior in various negotiation situations, experimental economics, as well as formal sciences such as decision and game theory, attempts to build prescriptive or constitutive models which would guide dealmakers' behavior towards obtaining coherent outcomes (Wachowicz \& Wu, 2010). Negotiation is an intercommunication-based process between entities who seek to reach a tangible agreement based on common interests while optimizing their

\footnotetext{
* Doctoral School of Economics and Business Administration, "Alexandru Ioan Cuza" University of Iasi, Romania
} 
individual utilities. This beneficial outcome can be for all the parties involved, or just for one or some of them (Adnan, et al, 2016). The issue of objective and subjective achievements from the negotiation process forms the foundation of many studies (Curhan et al, 2006, Hindriks et al, 2007, Gelfand et al., 2006, Elfenbein et al, 2008, Carmon \& Ariely, 2000). Studies also analyzed the role of individual differences in the context of inherently interpersonal, dyadic interactions. After all, one-on-one negotiation involves two well-defined interaction partners, both of whom may influence the negotiation outcomes (Elfenbein et al, 2008). Negotiations are one of the most essential components in business success (Herbst and Schwarz 2011, cited in Sigurðardóttir et al, 2019). Negotiation outcomes affect the development of negotiated relationships. Interactions after negotiations are likely to be the norm in today's business markets, as sales and marketing personnel work toward building long-term customer relationships (Gordon, 1999, cited in Patton \& Balakrishnan, 2010). The relationship throughout the negotiations reflects the personality and behavior of both parties who are characterized by a different personality and attitude they bring to the negotiation table. Once they know the tendency, the personal motivation of themselves as well as of the other party, it is possible to start dealing with strategy (Thompson, 2001).

Novel literature deals with different aspects of negotiation such as characterization of negotiation behavior (Saorín-Iborraa \& Cubillo, 2019), the expectation of future negotiation interaction on bargaining processes and outcomes (Patton\& Balakrishnan, 2010), and power and negotiation (Schaerer et al, 2020). However, "there is a lack of information about what actually occurs during business negotiations in general" despite the importance of the negotiation to the success of business strategies, (Fells et al. 2015) and how practitioners behave in business-to-business (B2B) settings (Agndal, Age, and Frick 2017, cited in Sigurðardóttir et al, 2019).

Satisfaction has distinctly important implications given the evidence of the correlation between cooperation and the desire for unremitting relationships (Barry and Oliver, 1996; Heide and Miner, 1992; Oliver et al., 1994; Purdy et al., 2000, cited in Patton \& Balakrishnan, 2010). Negotiators in the business market are categorized into different bargaining styles and personal flexibility characteristics. It is worth questioning whether the direct main effects of individual differences have any predictive power for negotiation subjective performance. This study takes a deliberatively exploratory approach to the question of how an encounter between negotiation bargaining styles and 
flexibility characteristics affects the subjective negotiation outcomes among professionals involved in ongoing negotiations in the business market.

\section{THEORY AND HYPOTHESIS}

Both parties to the negotiation experience the process through their personal perception. Negotiation processes include negotiators' behaviors, cognitions, emotions, and motivations. The interpersonal system alludes to the ways that negotiators' behavior and end results depend upon the presence of the other party or parties - negotiations in the context of others, and the dyadic aspects of negotiation behavior (Thompson et al, 2010).

When we explore the ways negotiators refer to changes, we must investigate relevant aspects and definitions in their personality that affect the process. Personality concerns compositions in an individuals' behavior that re-emerges in various situations. Personality traits are labels that summarize those compositionss (Gelfand et al, 2006) personal flexibility and bargaining style represent different and wide aspects of both sides of the negotiation by which different attitudes of both sides affect the subjective value each side claims from the process and the outcomes of the negotiation. Psychological flexibility refers to the ability to be open, presentfocused, and to change or persist in behavior according to changing internal and external circumstances (Ben-Itzhak et al, 2014). The Psychological Flexibility Questionnaire (PFQ) was chosen as a valid questionnaire for this purpose. ThomasKilmann Instrument (TKI) is a valid psychometric test to measure negotiators' profile within the two-dimensional space of assertiveness and cooperativeness (Thomas and Kilmann, 1977, 1988, 1992, 2002) (Wachowicz \& Wu, 2010). In a four-factor model of subjective value (SV), negotiators subjectively evaluate success on four dimensions. As such, the umbrella construct of SV represents an integrative framework that connects existing lines of negotiation research on related topics such as trust, justice, relationships, and outcome satisfaction (Curhan et al, 2006). Besides striving for a satisfying instrumental outcome (e.g., reaching goals), negotiators strive for a positive self-view as a negotiator (e.g., feeling competent, living up to one's principles), a good relationship with the counterpart, and an effective negotiation process. The SV resulting from a negotiation may feedback, positively or negatively, into future objective outcomes (Elfenbein, et al, 2008). 


\section{Hypothesis}

Based on the theory discussed above, the following hypotheses are proposed:

H1- There is a positive relationship between Psychological Flexibility and Subjective Value Inventory: the higher the level of flexibility in personality traits, the higher the likelihood of satisfaction from the negotiation.

H2- There is a relationship between the Assertiveness and Cooperativeness and the Subjective Value Inventory.

H3- There is a relationship between Assertiveness and Cooperativeness and Psychological Flexibility.

H4- The relationship between Psychological Flexibility and the Subjective Value Inventory is moderated by Assertiveness and Cooperativeness

H4.1- The relationship between Psychological Flexibility and the Subjective Value Inventory is moderated by conflict instrument- competing

H4.2- The relationship between Psychological Flexibility and the Subjective Value Inventory is moderated by conflict instrument- collaborating

H4.3- The relationship between Psychological Flexibility and the Subjective Value Inventory is moderated by conflict instrument- compromise

H4.4- The relationship between Psychological Flexibility and the Subjective Value Inventory is moderated by conflict instrument- avoiding

H4.5- The relationship between Psychological Flexibility and the Subjective Value Inventory is moderated by conflict instrument- Accommodating

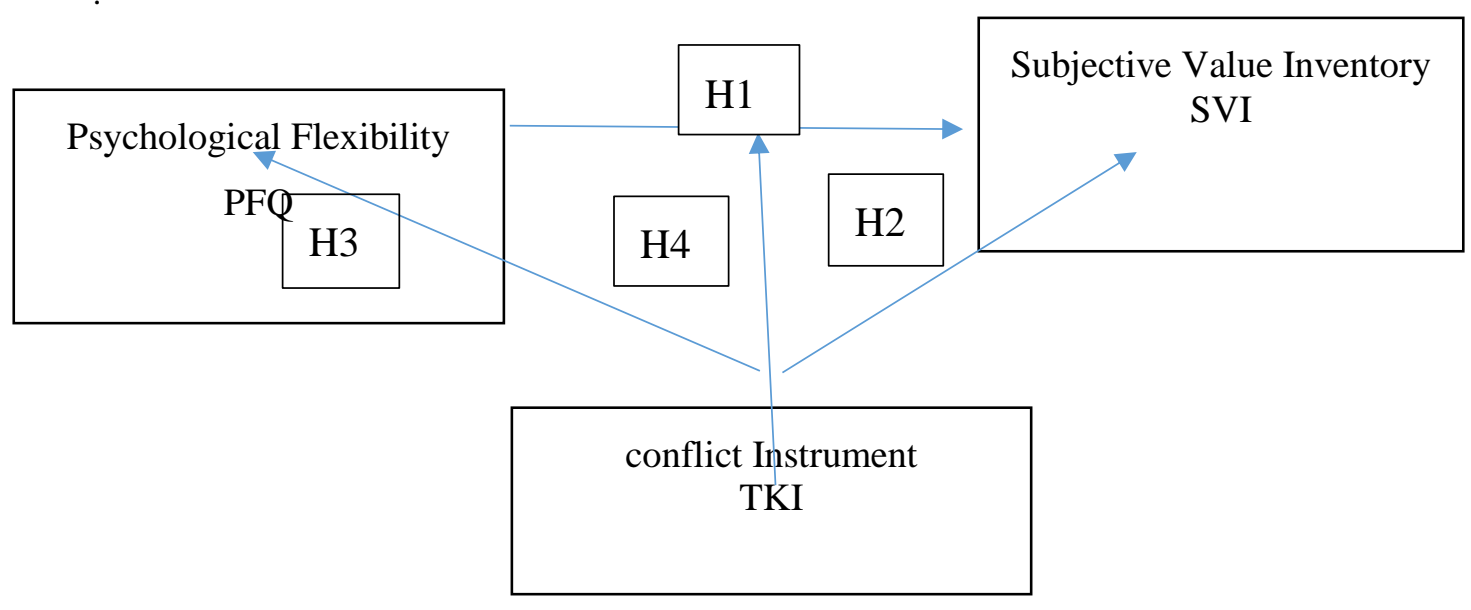

Figure 1. Research Model with Hypotheses 


\section{Methodology}

In the line with the study assumptions ( $\mathrm{H} 1, \mathrm{H} 2, \mathrm{H} 3, \mathrm{H} 4$ Hypotheses), the three well-established reflective scales from the literature were used to measure the constructs (PFQ-5 items, TKI-5 items, SVI-4 items). The conceptual model is presented in figure 1, and a questionnaire was applied to collect the data, as detailed below. In the first part, PFQ and TKI were used as Independent variables and SVI as dependent. In the second part, TKI was used as a moderator variable between PFQ and SVI. Different characteristics were chosen as control variables, in the demographic field (gender, age, education) and in the professional field (role, seniority in the current position, and years of experience in the field).

\section{Measuring scales:}

PFQ: The research questionnaire used the Likert scale (1-6). The variable and dimensions were calculated by averaging the scores in the items of each dimension, creating a new scale of the quasi-interval type whose range is between $1-6$.

SVI: The research questionnaire used the Likert scale (1-7). The variable and dimensions were calculated by averaging the scores in the items of each dimension, creating a new scale of the quasi-interval type whose range is between $1-7$.

TKI: The conflict-instrument-questionnaire: The five dimensions of the variable were created by plotting the number of times the respondent marked certain answers. In the AVOIDING dimension the score range is 1-13, while in the other dimensions 1-12. The measurement scale is an interval scale.

Table 1 Measuring scales:

\begin{tabular}{|c|c|c|c|c|}
\hline Variable & & scale & $\begin{array}{l}\text { Questionnaire } \\
\text { Range }\end{array}$ & $\begin{array}{l}\text { Variable } \\
\text { scale }\end{array}$ \\
\hline PFQ & $\begin{array}{l}\text { Psychological Flexibility } \\
\text { Questionnaire }\end{array}$ & Likert & $1-6$ & $\begin{array}{l}\text { Quasi- } \\
\text { interval }\end{array}$ \\
\hline SVI & $\begin{array}{ll}\text { Subjective } & \text { Value } \\
\text { Inventory } & \\
\end{array}$ & Likert & $1-7$ & $\begin{array}{l}\text { Quasi- } \\
\quad \text { interval }\end{array}$ \\
\hline TKI & $\begin{array}{l}\text { conflict-instrument- } \\
\text { questionnaire }\end{array}$ & Nominal/ & $1-12 / 1-13$ & Interval \\
\hline
\end{tabular}

\section{Population}

The target population of the study were people who work in the high-tech industry, and as part of their role are engaged in managing negotiations with customers and/or suppliers.

Data collection and sample 
A sample of respondents from the High-tech arena who by virtue of their position have access to customers or suppliers were invited to take part in the study. In the first stage, about 17 people whom the researcher knew and met the above basic criteria were contacted and asked to fill out a questionnaire. Also, a link to a questionnaire was published in two users on the LinkedIn network, and it is estimated that around 5-10 more respondents came from this source. 39 participants completed the questionnaires. As mentioned, the population suitable for the study is a very specific population. Therefore, in order to reach only those respondents who meet the criteria set by the researcher (high-tech industry, a role that negotiates with customers or suppliers), it was necessary to use a personal acquaintance network (intentional sampling) and expand it through the second circle of acquaintances (snowball sampling). For sample characteristics see Appendix.

\section{Instrument and procedure}

Quantitative analysis was used to perform hypothesis testing, by using a fourchapter closed structured questionnaire as a data collected instrument.

\section{Findings}

Hypothesis number 1: There is a positive relationship between Psychological Flexibility (PFQ) and Subjective Value Inventory (SVI): the higher the level of flexibility in personality traits, the higher the likelihood of satisfaction from the negotiation. To examine whether there is a correlation between Psychological Flexibility and Subjective Value Inventory, Spearman correlation coefficient was calculated, as shown in Table 2.

Table 2 Spearman coefficient between Psychological Flexibility and Subjective Value Inventory

\begin{tabular}{|c|c|c|c|c|c|}
\hline \multirow[b]{2}{*}{ Psychological Flexibility } & \multicolumn{5}{|c|}{ Subjective Value Inventory } \\
\hline & $\begin{array}{c}\text { Instrumental } \\
\text { Outcome }\end{array}$ & Self & Process & relationship & $\begin{array}{l}\text { SVI- } \\
\text { SUM }\end{array}$ \\
\hline positive perception of change & $.462^{* *}$ & .309 & $.377^{*}$ & $.580^{* *}$ & $.533^{* *}$ \\
\hline $\begin{array}{l}\text { characterization of the self as } \\
\text { flexible }\end{array}$ & .060 & .072 & .133 & -.006 & .003 \\
\hline $\begin{array}{c}\text { characterization of the self as } \\
\text { open and innovative }\end{array}$ & .087 & .027 & .120 & .252 & .177 \\
\hline $\begin{array}{l}\text { a perception of reality as } \\
\text { dynamic and changing }\end{array}$ & .262 & .281 & .188 & .277 & .300 \\
\hline $\begin{array}{l}\text { a perception of reality as } \\
\text { multifaceted }\end{array}$ & .164 & .014 & .023 & .036 & .034 \\
\hline PFQ-SUM & .143 & .058 & .171 & .159 & .144 \\
\hline
\end{tabular}


The table shows a clear trend according to which only the positive perception of change dimension (in the PFQ variable) has significant positive correlations with the Subjective Value Inventory ( $\mathrm{rs}=.53 \mathrm{p}<.01)$, as well as International outcome ( $\mathrm{rs}=.46 ; \mathrm{p}<.01)$, Relationship ( $\mathrm{rs}=.58 ; \mathrm{p}<.01$ ) and process $(\mathrm{rs}=.38 ; \mathrm{p}<.05)$. This implies that the higher the level of positive perception of change of the respondent, the higher the probability that he will express a higher level of Subjective Value Inventory. For the other dimensions of Psychological Flexibility, no significant correlations were found with the Subjective Value Inventory. It is important to emphasize that sample size $(\mathrm{N}=39)$ has a large effect on the level of significance in the Spearman test, and although there are some correlations in the range $0.20-0.30$ they are not statistically significant.

Based on the findings it can be determined that the hypothesis was confirmed only in the positive perception of change dimension and was rejected in the other dimensions of Psychological Flexibility.

Hypothesis number 2: There is a relationship between the conflict instrument and the Subjective Value Inventory.

To examine whether there is a correlation between Subjective Value Inventory and Conflict Instrument, Spearman correlation coefficient is calculated, as shown in Table 3.

Table 3 Spearman coefficient between Subjective Value Inventory and Conflict Instrument

\section{conflict-instrument}

\begin{tabular}{lccccc}
\hline $\begin{array}{l}\text { Subjective } \\
\text { Value } \\
\text { Inventory }\end{array}$ & competing & Collaborating & compromise & avoiding & Accommodating \\
\hline Instrumental & -.170 & .154 & .128 & -.092 & -.031 \\
Outcome & -.135 & .012 & .108 & .011 & .093 \\
Self & -.192 & .082 & .250 & -.002 & -.150 \\
Process & -.242 & .159 & .274 & -.044 & -.155 \\
Relationship & -.286 & .174 & .252 & -.061 & -.077 \\
SVI-SUM & & & & & \\
\hline
\end{tabular}

The table shows that there are no significant correlations between Subjective Value Inventory and conflict instrument. Based on the findings, it appears that the hypothesis was rejected. 
Hypothesis number 3: There is a relationship between the conflict instrument and the Psychological Flexibility.

To examine whether there is a correlation between Psychological Flexibility and Conflict Instrument, Spearman coefficient is calculated, as shown in Table 4.

Table 4

Spearman coefficient between Psychological Flexibility and Conflict Instrument

conflict-instrument

\begin{tabular}{lccccc}
\hline $\begin{array}{l}\text { Psychological } \\
\text { Flexibility }\end{array}$ & $\begin{array}{c}\text { competin } \\
\mathrm{g}\end{array}$ & $\begin{array}{c}\text { Collaboratin } \\
\mathrm{g}\end{array}$ & $\begin{array}{c}\text { Compromis } \\
\mathrm{e}\end{array}$ & $\begin{array}{c}\text { avoidin } \\
\mathrm{g}\end{array}$ & $\begin{array}{c}\text { Accommodatin } \\
\mathrm{g}\end{array}$ \\
\hline $\begin{array}{l}\text { positive } \\
\text { perception of } \\
\text { change }\end{array}$ & -.059 & .104 & .055 & -.028 & -.074 \\
$\begin{array}{l}\text { characterizatio } \\
\text { n of the self as }\end{array}$ & -.084 & -.071 & .012 & .234 & .016 \\
$\begin{array}{l}\text { flexible } \\
\text { characterizatio } \\
\text { n of the self as }\end{array}$ &.$- .353^{*}$ & .211 & .261 & -.152 & .030 \\
$\begin{array}{l}\text { open and } \\
\text { innovative }\end{array}$ & & & & & \\
$\begin{array}{l}\text { a perception of } \\
\text { reality as } \\
\text { dynamic and } \\
\text { changing }\end{array}$ & -.112 & .165 & .053 & -.087 & .076 \\
$\begin{array}{l}\text { a perception of } \\
\text { reality as } \\
\text { multifaceted }\end{array}$ & .018 & -.047 & -.058 & .111 & -.017 \\
PFQ - SUM & -.182 & .047 & .074 & .036 & .104 \\
\hline (*) p<0.05 & & & & & \\
\hline
\end{tabular}

The table shows only one significant negative correlation between the characterization of the self as open and innovative (in the PFQ variable) and the competing dimension ( $\mathrm{rs}=-.35 ; \mathrm{p}<.05)$ : this means that those who characterize themselves as open and innovative will not take a competitive approach as a means of conflict resolution. Apart from the significant correlation between competing and characterization of the self as open and innovative, the hypothesis was rejected.

Hypothesis number 4: The relationship between Psychological Flexibility and the Subjective Value Inventory is moderated by a conflict instrument.

The above hypotheses (4.1-4.5) were tested in several stages, as detailed. In the first stage, I divided the respondents into two groups in each of the five styles of conflict instrument. The division was made according to the value closest to the median, so that two representative groups could be obtained, given the fact that the 
sample is small. Table no 4 below shows the distribution according to the classification of groups as low/high in each of the styles of conflict instrument.

Table 5

\begin{tabular}{|l|c|c|c|c|c|c|c|c|c|c|}
\hline & \multicolumn{2}{|c|}{ Competing } & \multicolumn{2}{c|}{ collaborating } & \multicolumn{2}{c|}{ compromise } & \multicolumn{2}{c|}{ Avoiding } & \multicolumn{2}{c|}{ Accommodating } \\
\hline & $\mathrm{N}$ & $\%$ & $\mathrm{~N}$ & $\%$ & $\mathrm{~N}$ & $\%$ & $\mathrm{~N}$ & $\%$ & $\mathrm{~N}$ & $\%$ \\
\hline Low & 24 & 61.5 & 20 & 51.3 & 20 & 51.3 & 18 & 46.2 & 21 & 53.8 \\
\hline High & 15 & 38.5 & 19 & 48.7 & 19 & 48.7 & 21 & 53.8 & 18 & 46.2 \\
\hline
\end{tabular}

In the second stage, I performed Spearman Coefficient analysis between the independent variable - Psychological Flexibility, and the dependent variable Subjective Value Inventory, in each subgroup (low/high) separately. I performed the comparative analysis 5 times, depending on the number of conflict instrument factors. To examine whether the conflict instrument moderates the relationship between Psychological Flexibility and Subjective Value Inventory, I compared the correlations in the high/low groups, as shown in the following tables.

Hypothesis number 4.1: The relationship between Psychological Flexibility and the Subjective Value Inventory is moderated by conflict instrument- competing

Table 6 Spearman coefficient between Psychological Flexibility and Subjective Value Inventory, among a low competing group compared to a high competing group

\begin{tabular}{|c|c|c|c|c|c|c|c|c|c|c|}
\hline competing & low & high & low & high & low & high & Low & high & low & high \\
\hline & \multicolumn{2}{|c|}{$\begin{array}{l}\text { Instrumental } \\
\text { Outcome }\end{array}$} & \multicolumn{2}{|c|}{ Self } & \multicolumn{2}{|c|}{ Process } & \multicolumn{2}{|c|}{ relationship } & \multicolumn{2}{|c|}{ SATIS_SUM } \\
\hline $\begin{array}{l}\text { positive } \\
\text { perception of } \\
\text { change }\end{array}$ & .420 & .486 & .162 & .555 & $\begin{array}{r}434 \\
*\end{array}$ & .350 & $\begin{array}{r}.740^{*} \\
*\end{array}$ & .304 & $.535_{*}^{*}$ & $.641_{*}$ \\
\hline $\begin{array}{l}\text { characterizatio } \\
\mathrm{n} \text { of the self as } \\
\text { flexible }\end{array}$ & .026 & .004 & .061 & .303 & .204 & .164 & .037 & .156 & .027 & .025 \\
\hline $\begin{array}{l}\text { characterizatio } \\
\mathrm{n} \text { of the self as } \\
\text { open and } \\
\text { innovative }\end{array}$ & .061 & .131 & .072 & .107 & .054 & .172 & .166 & .501 & .022 & .475 \\
\hline $\begin{array}{l}\text { a perception of } \\
\text { reality as } \\
\text { dynamic and } \\
\text { changing }\end{array}$ & .214 & .127 & .217 & .496 & .153 & .210 & .205 & .276 & .189 & .421 \\
\hline $\begin{array}{l}\text { a perception of } \\
\text { reality as } \\
\text { multifaceted }\end{array}$ & .040 & .363 & .174 & .484 & .007 & .016 & -.147 & .252 & -.161 & .390 \\
\hline PFQ_SUM & .018 & .149 & .149 & .426 & .137 & .009 & .047 & .158 & -.035 & .310 \\
\hline
\end{tabular}

(**) $p<0.01 ;(*) p<0.05$ 
In all pairs of correlations marked in red, significant differences were found between the correlations, indicating that the competing dimension moderates the relationship between Psychological Flexibility and Subjective Value Inventory. In the group of "high competing", the correlations between the dimensions of Psychological Flexibility and the self-dimension are positive and significant, while among the "low competing" group the correlations between the variables are low or do not exist at all. That is, competing is found as an intervening variable in the relationship between Psychological Flexibility and Subjective Value Inventory. In people characterized by a high level of competing, a positive correlation between Psychological Flexibility and Subjective Value Inventory is more likely. The gaps in the correlations indicate that competing is an intervening variable in the relationship between Psychological Flexibility and Subjective Value Inventory. Given the findings, it can be determined that the research hypothesis was partially confirmed, since the gaps in correlations exist with respect to about half of the dimensions and not all of them.

Hypothesis number 4.2: The relationship between Psychological Flexibility and the Subjective Value Inventory is moderated by conflict instrumentcollaboration

Table 7 Spearman coefficient between Psychological Flexibility and Subjective Value Inventory, among a low collaborating group compared to a high collaborating group

\begin{tabular}{|c|c|c|c|c|c|c|c|c|c|c|}
\hline collaborating & low & high & low & high & low & high & Low & high & low & high \\
\hline & \multicolumn{2}{|c|}{$\begin{array}{l}\text { Instrumental } \\
\text { Outcome }\end{array}$} & \multicolumn{2}{|c|}{ Self } & \multicolumn{2}{|c|}{ Process } & \multicolumn{2}{|c|}{ relationship } & SATIS & SUM \\
\hline $\begin{array}{l}\text { positive } \\
\text { perception of } \\
\text { change }\end{array}$ & .340 & .510 & .415 & .139 & $\begin{array}{r}- \\
.058\end{array}$ & $.615^{*}$ & .386 & $.734^{*}$ & .278 & $.654^{*}$ \\
\hline $\begin{array}{l}\text { characterizatio } \\
\mathrm{n} \text { of the self as } \\
\text { flexible } \\
\text { characterizatio }\end{array}$ & $.165^{-}$ & .259 & .189 & .288 & .183 & $.531^{*}$ & .438 & $.576_{*}^{*}$ & $.442^{-}$ & $.543^{*}$ \\
\hline $\begin{array}{l}\mathrm{n} \text { of the self as } \\
\text { open and } \\
\text { innovative }\end{array}$ & $\begin{array}{r}- \\
.176\end{array}$ & .246 & .247 & .215 & $.142^{-}$ & .369 & .047 & .447 & $\begin{array}{r}- \\
.073\end{array}$ & .338 \\
\hline $\begin{array}{l}\text { a perception of } \\
\text { reality as } \\
\text { dynamic and } \\
\text { changing }\end{array}$ & .003 & .312 & .113 & $.602^{*}$ & $228^{-}$ & $.468^{*}$ & .003 & .307 & .142 & $.498^{*}$ \\
\hline $\begin{array}{l}\text { a perception of } \\
\text { reality as } \\
\text { multifaceted }\end{array}$ & .153 & .269 & .256 & .366 & $.21 \overline{6}$ & .357 & $.175^{-}$ & .304 & $.208^{-}$ & .349 \\
\hline PFQ_SUM & $\begin{array}{r}- \\
.060\end{array}$ & .287 & .221 & .274 & .227 & $.570^{*}$ & $.194^{-}$ & $.546^{*}$ & .264 & $.537^{*}$ \\
\hline
\end{tabular}


In all pairs of correlations marked in red, significant differences were found between the correlations, indicating that the collaborating dimension moderates the relationship between Psychological Flexibility and Subjective Value Inventory. The table shows that there is a clear trend of differences in the correlation pairs. In the "high collaboration" group there are relatively high positive correlations between all dimensions of Psychological Flexibility and Subjective Value Inventory, while in the "low collaboration" group the correlations are low and, in some cases, negative. This means that collaboration moderates the connections between Psychological Flexibility and Subjective Value Inventory. The condition for a significant positive relationship between Psychological Flexibility and Subjective Value Inventory is a high level of collaboration in conflict management. It can therefore be determined that the research hypothesis was confirmed.

Hypothesis number 4.3: The relationship between Psychological Flexibility and the Subjective Value Inventory is moderated by conflict instrumentcompromise

Table 8 Spearman correlation coefficient between Psychological Flexibility and Subjective Value Inventory, among a low compromise group compared to a

high compromise group

\begin{tabular}{|c|c|c|c|c|c|c|c|c|c|c|}
\hline compromise & low & $\begin{array}{l}\text { hig } \\
\mathrm{h}\end{array}$ & low & high & low & high & Low & high & low & high \\
\hline & \multicolumn{2}{|c|}{$\begin{array}{l}\text { Instrumental } \\
\text { Outcome }\end{array}$} & \multicolumn{2}{|c|}{ Self } & \multicolumn{2}{|c|}{ Process } & \multicolumn{2}{|c|}{ relationship } & \multicolumn{2}{|c|}{ SATIS_SUM } \\
\hline $\begin{array}{l}\text { positive } \\
\text { perception of } \\
\text { change }\end{array}$ & $.637^{*}$ & .315 & $\begin{array}{r}.530 \\
*\end{array}$ & .044 & .366 & .377 & $.669^{*}$ & .513 & $.692^{*}$ & .380 \\
\hline $\begin{array}{l}\text { characterizatio } \\
\mathrm{n} \text { of the self as } \\
\text { flexible }\end{array}$ & -.007 & .127 & .031 & .023 & .018 & .293 & -.205 & .264 & -.164 & .183 \\
\hline $\begin{array}{l}\text { characterizatio } \\
\mathrm{n} \text { of the self as } \\
\text { open and } \\
\text { innovative }\end{array}$ & -.103 & .115 & .124 & .057 & .165 & .017 & .257 & .192 & .174 & .127 \\
\hline $\begin{array}{lr}\text { a perception of } \\
\text { reality as } \\
\text { dynamic and } \\
\text { changing }\end{array}$ & .341 & .151 & .360 & .199 & .477 & .031 & $.529^{*}$ & .116 & $.554^{*}$ & .187 \\
\hline $\begin{array}{l}\text { a perception of } \\
\text { reality as } \\
\text { multifaceted }\end{array}$ & .244 & .081 & .122 & .112 & .266 & .156 & .105 & .038 & .185 & .052 \\
\hline PFQ_SUM & .223 & .071 & .080 & $\begin{array}{r}- \\
.108^{-}\end{array}$ & .245 & .093 & .188 & .157 & .216 & .100 \\
\hline
\end{tabular}

(**) $p<.01 ;(*) p<0.05$ 
In all pairs of correlations marked in red, significant differences were found between the correlations, indicating that the compromise dimension moderates the relationship between Psychological Flexibility and Subjective Value Inventory. The table shows that there is a trend of differences in the correlation pairs. In the "low compromise" group there are relatively high positive correlations between Psychological Flexibility and Subjective Value Inventory, while in the "high compromise" group the correlations are very low or do not exist at all. This means that compromise moderates the connections between Psychological Flexibility and Subjective Value Inventory. The condition for a significant positive relationship between Psychological Flexibility and Subjective Value Inventory is a low level of compromise in conflict management. It can therefore be determined that the research hypothesis was confirmed only partly.

Hypothesis number 4.4: The relationship between Psychological Flexibility and the Subjective Value Inventory is moderated by conflict instrument- avoiding.

Table 9 Spearman coefficient between Psychological Flexibility and Subjective Value Inventory, among a low Avoiding group compared to a high Avoiding group

\begin{tabular}{|c|c|c|c|c|c|c|c|c|c|c|}
\hline Avoiding & low & high & low & high & low & high & Low & High & low & high \\
\hline & \multicolumn{2}{|c|}{$\begin{array}{l}\text { Instrumental } \\
\text { Outcome }\end{array}$} & \multicolumn{2}{|c|}{ Self } & \multicolumn{2}{|c|}{ Process } & \multicolumn{2}{|c|}{ Relationship } & \multicolumn{2}{|c|}{ SATIS_SUM } \\
\hline $\begin{array}{l}\text { positive } \\
\text { perception of } \\
\text { change }\end{array}$ & .436 & $.462^{*}$ & .061 & $\begin{array}{r}.586^{*} \\
*\end{array}$ & $.536^{*}$ & .114 & $.611_{*}^{*}$ & $\begin{array}{r}.559^{*} \\
*\end{array}$ & .566 & $.562^{*}$ \\
\hline $\begin{array}{l}\text { characterizatio } \\
n \text { of the self as } \\
\text { flexible }\end{array}$ & .092 & .282 & $.230^{-}$ & .348 & .135 & .156 & -.030 & -.024 & .083 & .043 \\
\hline $\begin{array}{l}\text { characterizatio } \\
n \text { of the self as } \\
\text { open and } \\
\text { innovative }\end{array}$ & .091 & -.004 & .156 & .172 & .235 & .029 & .061 & .235 & .042 & .250 \\
\hline $\begin{array}{lr}\text { a perception of } \\
\text { reality as } \\
\text { dynamic and } \\
\text { changing }\end{array}$ & $\begin{array}{r}- \\
.088\end{array}$ & $.636_{*}^{*}$ & .148 & $.517^{*}$ & .022 & .237 & .095 & .381 & .077 & $.482^{*}$ \\
\hline $\begin{array}{l}\text { a perception of } \\
\text { reality as } \\
\text { multifaceted }\end{array}$ & .127 & $.434^{*}$ & .082 & .054 & $\begin{array}{r}0.00 \\
0\end{array}$ & $\begin{array}{r}- \\
.009\end{array}$ & .111 & -.063 & .027 & .002 \\
\hline PFQ_SUM & $\begin{array}{r}- \\
.139 \\
\end{array}$ & .370 & $\begin{array}{r}- \\
.208\end{array}$ & .338 & .135 & .171 & -.021 & .216 & $\begin{array}{r}- \\
.078\end{array}$ & .279 \\
\hline
\end{tabular}

(**) $p<.01 ;(*) p<0.05$

In all pairs of correlations marked in red, significant differences were found between the correlations, indicating that the Avoiding dimension moderates the relationship between Psychological Flexibility and Subjective Value Inventory. The table shows that there is a trend of differences in the correlation pairs. In the "high 
avoiding" group there are relatively high positive correlations between dimensions of Psychological Flexibility and Subjective Value Inventory, while in the "low avoiding" group the correlations are low or do not exist at all. This means that avoiding moderates the connections between Psychological Flexibility and Subjective Value Inventory. The condition for a significant positive relationship between Psychological Flexibility and Subjective Value Inventory is a high level of avoidance in conflict management. It can therefore be determined that the research hypothesis was confirmed partially.

Hypothesis number 4.5: The relationship between Psychological Flexibility and the Subjective Value Inventory is moderated by conflict instrumentaccommodating

Table 10 Spearman coefficient between Psychological Flexibility and Subjective Value Inventory, among a low Accommodating group compared to a

high Accommodating group

\begin{tabular}{|c|c|c|c|c|c|c|c|c|c|c|}
\hline \multirow[t]{2}{*}{ Accommodating } & low & high & low & high & low & high & low & high & Low & high \\
\hline & \multicolumn{2}{|c|}{$\begin{array}{l}\text { Instrumental } \\
\text { Outcome }\end{array}$} & \multicolumn{2}{|c|}{ Self } & \multicolumn{2}{|c|}{ Process } & \multicolumn{2}{|c|}{ relationship } & \multicolumn{2}{|c|}{ SATIS_SUM } \\
\hline $\begin{array}{l}\text { positive } \\
\text { perception of } \\
\text { change }\end{array}$ & $.602^{* *}$ & .273 & $.521^{*}$ & .080 & .416 & .260 & $.596^{* * *}$ & $.599^{* *}$ & $.699^{* * *}$ & .325 \\
\hline $\begin{array}{l}\text { characterization } \\
\text { of the self as } \\
\text { flexible }\end{array}$ & .104 & -.081 & .314 & -.220 & .064 & .148 & .078 & -.136 & .143 & -.175 \\
\hline $\begin{array}{l}\text { characterization } \\
\text { of the self as open } \\
\text { and innovative }\end{array}$ & .098 & .120 & .288 & -.233 & -.026 & .368 & .219 & .266 & .207 & .178 \\
\hline $\begin{array}{l}\text { a perception of } \\
\text { reality as dynamic } \\
\text { and changing }\end{array}$ & .184 & .340 & $.436^{*}$ & .011 & .206 & .205 & .337 & .350 & .431 & .213 \\
\hline $\begin{array}{l}\text { a perception of } \\
\text { reality as } \\
\text { multifaceted }\end{array}$ & .139 & .154 & .195 & -.247 & -.096 & .233 & .130 & -.033 & .152 & -.037 \\
\hline PFQ_SUM & .206 & .052 & .358 & -.378 & .087 & .384 & .259 & .194 & .309 & .062 \\
\hline
\end{tabular}

$(* *) p<.01 ;(*) p<0.05$

In all pairs of correlations marked in red, significant differences were found between the correlations, indicating that the Accommodating dimension moderates the relationship between Psychological Flexibility and Subjective Value Inventory. The table shows that there is a trend of differences in the correlation pairs. In the "low Accommodating" group there are relatively high positive correlations between dimensions of Psychological Flexibility and Subjective Value Inventory, while in the "high Accommodating" group the correlations are very low or do not exist at all. 
This means that Accommodating moderates the connections between Psychological Flexibility and Subjective Value Inventory. The condition for a significant positive relationship between Psychological Flexibility and Subjective Value Inventory is a low level of Accommodating in conflict management. Given the findings, it can be determined that the research hypothesis was partially confirmed, since the gaps in correlations exist with respect to about half of the dimensions and not all of them.

\section{The relationship between respondent characteristics and research variables}

To test whether there are differences in the rankings of men and women in the research variables, I used the t-test for independent samples. The findings indicate that there are no significant differences between men and women in all the variables examined. A similar statistical test was conducted to examine whether there are differences between Israelis and non-Israelis, as well as whether there are differences between those with a bachelor's degree compared to higher degrees. In these tests, too, no significant differences were found between the groups.

The correlation between the age and experience of the respondents and the research variables was examined using the Pearson correlation and with Spearman Nonparametric correlation coefficient test. No significant correlations were found, however, I found 3 correlations at the significance level between 0.05-0.10, as detailed: a positive correlation between a perception of reality as dynamic and changing and age $(\mathrm{r}=.29 ; \mathrm{p}=.07)$ and experience $(\mathrm{r}=.29 ; \mathrm{p}=.07)$, and a positive correlation between a perception of reality as multifaceted and age $(\mathrm{r}=.28 ; \mathrm{p}=.09)$. These findings show a relationship between age and professional experience regarding the level of flexibility in the above two dimensions.

The relationship between the respondent's role at work and Psychological Flexibility, Subjective Value Inventory, and conflict instrument was examined using one-way ANOVA test. No significant differences were found, meaning that the employee's role does not affect the style of coping in conflict situations, as well as on Psychological Flexibility, and Subjective Value Inventory.

Hypothesis

\begin{tabular}{|l|l|l|}
\hline H1 & $\begin{array}{l}\text { positive relationship between Psychological Flexibility and Subjective } \\
\text { Value Inventory: the higher the level of flexibility in personality traits, } \\
\text { the higher the likelihood of satisfaction from the negotiation }\end{array}$ & Partially \\
\hline H2 & $\begin{array}{l}\text { relationship between the Assertiveness and Cooperativeness and the } \\
\text { Subjective Value Inventory }\end{array}$ & Rejected \\
\hline H3 & $\begin{array}{l}\text { relationship between the Assertiveness and Cooperativeness and the } \\
\text { Psychological Flexibility }\end{array}$ & Rejected \\
\hline
\end{tabular}




\begin{tabular}{|l|l|l|}
\hline H4 & $\begin{array}{l}\text { The relationship between Psychological Flexibility and the Subjective } \\
\text { Value Inventory is moderated by Assertiveness and Cooperativeness }\end{array}$ & \\
\hline H4.1 & $\begin{array}{l}\text { The relationship between Psychological Flexibility and the Subjective } \\
\text { Value Inventory is moderated by conflict instrument- competing }\end{array}$ & Partially \\
\hline H4.2 & $\begin{array}{l}\text { The relationship between Psychological Flexibility and the Subjective } \\
\text { Value Inventory is moderated by conflict instrument- collaborating }\end{array}$ & Confirmed \\
\hline H4.3 & $\begin{array}{l}\text { The relationship between Psychological Flexibility and the Subjective } \\
\text { Value Inventory is moderated by conflict instrument- compromise }\end{array}$ & Partially \\
\hline H4.4 & $\begin{array}{l}\text { The relationship between Psychological Flexibility and the Subjective } \\
\text { Value Inventory is moderated by conflict instrument- } \text { avoiding }\end{array}$ & Partially \\
\hline H4.5 & $\begin{array}{l}\text { The relationship between Psychological Flexibility and the Subjective } \\
\text { Value Inventory is moderated by conflict instrument- Accommodating }\end{array}$ & Partially \\
\hline
\end{tabular}

\section{DisCuSSION AND CONCLUSIONS}

Due to the tremendous economic and social changes, negotiation research has dramatically grown both in breadth and depth in previous years ( $\mathrm{Li}$ et al, 2006). Business negotiation research necessitates studies that are focused on anticipated continued interactions between bargaining parties, since negotiations are based on the ongoing relationships in the business market, what (Heide and Miner, 1992; Roering, 1977, cited in Patton and Balakrishnan, 2010). While studying continued relations between parties, we must have a greater understanding of the negotiators themselves. In this study, I tried to understand clearly the triangular connection between flexibility, bargaining style, and subjective value inventory for negotiators. The study's findings reveal a few interesting insights. Those with a positive perception of change tend to perceive high subjective value. Bonds arise in business relationships as the two concomitant parties mutually acquire meaning in their reciprocal acts and interpretations because of the negotiator's perceptions (Håkansson \& Snehota, 1995, cited in Corsaro \& Snehota, 2012). It was found that of all the components of flexibility, the positive perception of change is the only one that predicts satisfaction among the parties.

Negotiators can come up with more productive solutions that can meet not only the delight of both sides but also increase the total value of the agreement in the frame of reference to integrative negotiation (as opposed to distributive) (Galinsky and Mußweiler, 2001; Park et al., 2013, cited in Barchi \& Greco, 2018). Successful negotiations are inherently connected to the negotiator's ability to create alternatives (Thompson, 2005 cited in Barchi \& Greco, 2018). From the five elements of flexibility, those who consider themselves as open and innovative tend to be less competitive and with a higher potential to lead an integrative negotiation. This unique combination sheds new light on negotiation in the high-tech sector. The findings indicate that among bargaining styles, collaboration appears to have a strong 
moderating effect on the connections between Psychological Flexibility and Subjective Value Inventory. Those with a collaborative approach tend to combine elements of flexibility to achieve higher subjective value from the negotiating process and outcome. These findings of Hypothesis $\mathrm{H} 4$ clarifies the findings of Hypothesis $\mathrm{H} 1, \mathrm{H} 2$, and $\mathrm{H} 3$ that show that those with a positive perception of change tend to perceive high subjective value (H1) Those who see reality as dynamic tend to have high self-satisfaction (H1). Those who perceive themselves as open and innovative tend to have a less competitive perception in negotiation (H3). A collaborative approach towards solutions tends to use more elements of flexibility to create more value.

\section{LIMITATIONS AND IMPLICATIONS FOR FUTURE STUDY}

Given the presented results, the limitations of the study should be addressed. The small sample size does represent a significant limitation. It would require repeating the study on a larger scale to conduct a statistically significant quantitative data analysis.

The quantitative study was conducted on participants from the high-tech sector, engaged in ongoing business negotiations, from the selling and the buying side. It is interesting to examine research results in front of dyads of negotiators around ongoing negotiations.

My qualitative findings suggest that additional research is required for an examination of the issue of compromise, along with being a pragmatic approach and mediating flexibility to satisfaction, whether it is a more competitive or more cooperative approach. Also, does it tend to strengthen ties between the parties to negotiations and how is it reflected in the various stages of business negotiations. Qualitative research will be able to answer at least some of these questions. 


\section{REFERENCES}

1. Adnan, M. H. M., Hassan, M. F., Aziz, I., \& Paputungan, I. V. (2015). Protocols for agent-based autonomous negotiations: A review.3rd International Conference on Computer and Information Sciences (ICCOINS). Kuala Lumpur, Malaysia: IEEE: 622-626.

2. Barchi, M., \& Greco, M. (2018). Negotiation in Open Innovation: A Literature Review. Group Decision and Negotiation, 27(3), 343-374. https://doi.org/10.1007/s10726-018-9568-8

3. Ben-Itzhak, S., Bluvstein, I., \& maor. (2014). The Psychological Flexibility Questionnaire (PFQ): Development, Reliability, and Validity.WebmedCentral PSYCHOLOGY 2014;5(4): WMC004606

4. Carmon, Z., \& Ariely, D. (2000). Focusing on the Forgone: How Value Can Appear So Different to Buyers and Sellers. Journal of Consumer Research, 27(3), 360-370. https://doi.org/10.1086/317590

5. Corsaro, D., \& Snehota, I. (2012). Perceptions of Change in Business Relationships and Networks. Industrial Marketing Management, 41(2), 270-286. https://doi.org/10.1016/j.indmarman.2012.01.002

6. Curhan, J. R., Elfenbein, H. A., \& Xu, H. (2006). What do people value when they negotiate? Mapping the domain of subjective value in negotiation. Journal of Personality and Social Psychology, 91(3), 493-512. https://doi.org/10.1037/0022-3514.91.3.493

7. Fells, R., Rogers, H., Prowse, P., \& Ott, U. F. (2015). Unraveling Business Negotiations Using Practitioner Data. Negotiation and Conflict Management Research, 8(2), 119-136. https://doi.org/10.1111/ncmr.12050

8. Gelfand, M. J., Major, V. S., Raver, J. L., Nishii, L. H., \& O’Brien, K. (2006a). Negotiating Relationally: The Dynamics of the Relational Self in Negotiations. Academy of Management Review, 31(2), 427-451. https://doi.org/10.5465/amr.2006.20208689

9. Gelfand, M. J., Major, V. S., Raver, J. L., Nishii, L. H., \& O’Brien, K. (2006b). Negotiating Relationally: The Dynamics of the Relational Self in Negotiations. Academy of Management Review, 31(2), 427-451. https://doi.org/10.5465/amr.2006.20208689

10. Hakansson, H., \& Snehota, I. (1995). THE BURDEN OF RELATIONSHIPS or WHO'S NEXT. https://www.escholar.manchester.ac.uk/api/datastream?publicationPid=uk-ac-manscw:2n491\&datastreamId=FULL-TEXT.PDF

11. Hindriks, K., Jonker, C., \& Tykhonov, D. (2007). Analysis of Negotiation Dynamics.Part of the Lecture Notes in Computer Science book series (LNCS, volume 4676)

12. Kilmann, R. H., \& Thomas, K. W. (1977). Developing a Forced-Choice Measure of ConflictHandling Behavior: The "Mode" Instrument. Educational and Psychological Measurement, 37(2), 309-325. https://doi.org/10.1177/001316447703700204

13. Li, M., Tost, L. P., \& Wade-Benzoni, K. (2006). The dynamic interaction of context and negotiator effects: A review and commentary on current and emerging areas in negotiation. International Journal of Conflict Management, 18(3), 222-259. https://www.academia.edu/186845/The_dynamic_interaction_of_context_and_negotiator_effect s_A_review_and_commentary_on_current_and_emerging_areas_in_negotiation

14. Patton, C., \& Balakrishnan, P. V. (Sundar). (2010). The impact of expectation of future negotiation interaction on bargaining processes and outcomes. Journal of Business Research, 63(8), 809-816. https://doi.org/10.1016/j.jbusres.2009.07.002

15. Saorín-Iborra, M. C., \& Cubillo, G. (2019). Supplier behavior and its impact on customer satisfaction: A new characterization of negotiation behavior. Journal of Purchasing and Supply 
Management, 25(1), 53-68. https://doi.org/10.1016/j.pursup.2018.03.002

16. Schaerer, M., Teo, L., Madan, N., \& Swaab, R. I. (2020). Power and negotiation: review of current evidence and future directions. Current Opinion in Psychology, 33(Volume 33, Pages 47-51), 47-51. https://doi.org/10.1016/j.copsyc.2019.06.013

17. Schuster, C., Majer, J. M., \& Trötschel, R. (2020). Whatever we negotiate is not what I like: How value-driven conflicts impact negotiation behaviors, outcomes, and subjective evaluations. Journal of Experimental Social Psychology, 90(90). https://doi.org/10.1016/j.jesp.2020.103993

18. Sigurðardóttir, A. G., Hotait, A., \& Eichstädt, T. (2019). Buyer and Seller Differences in Business-to-Business Negotiations. Negotiation Journal, 35(2), 297-331. https://doi.org/10.1111/nejo.12289

19. Thompson, L. L., Wang, J., \& Gunia, B. C. (2010). Negotiation. Annual Review of Psychology, 61(1), 491-515. https://doi.org/10.1146/annurev.psych.093008.100458

20. Wachowicz, T. and W., S, \& Wu, S. (2010). Describe the ways of Negotiators' strategies and their concessions. Https://Www.researchgate.net/Publication/280884024. 
General note regarding hypotheses 4.1-4.5: The current study model is exploratory. In the professional literature I have not found any study that examined a model that places the conflict instrument as an intervening variable in the relationship between Psychological Flexibility and the Subjective Value Inventory. Thus, I have no theoretical basis for assuming directional hypotheses, and therefore I will examine in the study the questions regarding whether the 5 dimensions of conflict instrument variables interfere with the relationship between the independent variable and the dependent variable.

\section{Supplementary data}

Sample characteristics

Table 1 The Sample Characteristics

\begin{tabular}{|l|l|l|l|}
\hline Vars. & Values. & $\mathbf{N}$ & $\mathbf{\%}$ \\
\hline Gender & Male & 30 & 76.9 \\
\hline & Female & 9 & 23.1 \\
\hline Country & Israel & 29 & 74.4 \\
\hline & Others $\left(^{*}\right)$ & 10 & 25.6 \\
\hline Age & $28-45$ & 12 & 30.8 \\
\hline & $46-55$ & 19 & 48.7 \\
\hline & $56-64$ & 8 & 20.5 \\
\hline Education & BA & 13 & 33.3 \\
\hline & MA, MBA, JD & 26 & 66.7 \\
\hline Role & sale & 22 & 56.4 \\
\hline & procurement & 3 & 7.7 \\
\hline & Product Architect & 5 & 12.8 \\
\hline & else & 9 & 23.1 \\
\hline Experience & $1-10$ years & 10 & 25.6 \\
\hline & $11-20$ years & 16 & 41.0 \\
\hline & $21-30$ years & 13 & 33.3 \\
\hline
\end{tabular}

(*) Others: includes - Canada, UK, USA, Singapore

The sample included 39 people, most of them from Israel (74.4\%) and some of them from other countries (as listed at the bottom of the table). Most of the sample consists of men (76.9\%) compared to a female minority (23.1\%). The average age in the sample is 49.5 years ( $\mathrm{SD}=7.67$ ), the age range is $28-64$. About one-third have a BA degree, and two-thirds have a master's degree or higher. More than half of the respondents in the sample are employed as salespeople (56.4\%), $12.8 \%$ of them product architects, $7.7 \%$ procurement, while $23.1 \%$ in other positions. I asked the subjects how many years of experience they have in the industry: about a quarter of them with 1-10 years of experience, $41.0 \%$ with $11-20$ years, while of $33.3 \%$ have $21-30$ years in the field. The average is 18.2 years $(\mathrm{SD}=8.86)$, in the range of 1-30 years. 